\title{
Thyroid Cancer pT1b TNM Finding v7
}

National Cancer Institute

\section{Source}

National Cancer Institute. Thyroid Cancer pT 1b TNM Finding v7. NCI Thesaurus. Code C89149.

Thyroid cancer with a tumor size of more than $1 \mathrm{~cm}$ but not more than $2 \mathrm{~cm}$ in greatest dimension, limited to the thyroid gland. (from AJCC 7th Ed.) 